\title{
A common protein export pathway in malaria parasites
}

\author{
Brendan Crabb ${ }^{1 *}$, Hayley Bullen ${ }^{1}$, Sarah Charnaud', Silvia Haase ${ }^{2}$, Justin Boddey ${ }^{3}$, Alan Cowman³, \\ Tania de Koning-Ward ${ }^{2}$, Paul Gilson ${ }^{1}$ \\ From Parasite to Prevention: Advances in the understanding of malaria \\ Edinburgh, UK. 20-22 October 2010
}

Protozoan parasites that cause malaria export hundreds of proteins into their host red blood cell cytosol, and some even beyond that to the extracellular environment. These proteins have a wide range of functions that are crucial to parasite virulence and/or parasite survival in the human host. It has been thought for some time that a common link to all these proteins is the mechanism by which they are exported. Recently, we have revealed much of how this export occurs, including the discovery of a novel translocon through which exported proteins must pass. As a common portal for many essential proteins this translocon becomes a strongly validated drug target.

\section{Author details}

'Burnet Institute, Melbourne 3004, Australia. ${ }^{2}$ School of Medicine, Deakin

University Waurn Ponds campus, Geelong 3217, Australia. ${ }^{3}$ Walter \& Eliza Hall

Institute, Parkville 3052, Australia.

Published: 20 October 2010

Cite this article as: Crabb et al:: A common protein export pathway in

malaria parasites. Malaria Journal 2010 9(Suppl 2):13.

Burnet Institute, Melbourne 3004, Australia

Full list of author information is available at the end of the article

Submit your next manuscript to BioMed Central and take full advantage of:

- Convenient online submission

- Thorough peer review

- No space constraints or color figure charges

- Immediate publication on acceptance

- Inclusion in PubMed, CAS, Scopus and Google Scholar

- Research which is freely available for redistribution

Submit your manuscript at www.biomedcentral.com/submit
() Biomed Central 